\title{
IMPLIKASI MODEL DESA KONSERVASI TERHADAP KESEJAHTERAAN MASYARAKAT SEKITAR KAWASAN KONSERVASI KPA/KSA KUNYI
}

\author{
ALAMSYAH*, ANDI NUDDIN, ABDUL AZIS AMBAR \\ PPs Agribisnis Universitas Muhammadiyah Parepare \\ Email : adnan.alamsyah.aa@gmail.com
}

\begin{abstract}
ABSTRAK
Program Model Desa Konservasi (MDK) merupakan model konservasi yang memberi peluang kepada masyarakat untuk terlibat aktif dan mendapat akses yang aman dalam pemanfaatan jangka panjang dalam mendukung konservasi kawasan hutan. Model akses pemanfaatan ini dapat berbeda-beda dari satu kawasan dengan kawasan lain tergantung pada kesepakatan pihak yang berwenang dalam pengelolaan kawasan. Penelitian ini bertujuan untuk mendeskripsikan implikasi program tersebut terhadap kesejahteraan masyarakat Desa Kunyi. Respons masyarakat berdasarkan 3 indikator, yaitu pengetahuan, sikap, dan keterampilan yang ditabulasi secara deskriptif kemudian dinilai dengan skala Likert dalam penilaian quisioner, dan pengukuran kategori data yang diperoleh menggunakan rumus Sturges. Hasil penelitian ini menyimpulkan bahwa program Model Desa Konservasi (MDK) dianggap berimplikasi positif terhadap kesejahteraan masyarakat di Desa Kunyi telah mampu memberi nilai tambah ekonomi masyarakat. namun nilai pendapatan ini pada dasarnya masih relatif kecil bila dibandingkan dengan kebutuhan masyarakat. Nilai pendapatan masyarakat sangat berpeluang untuk ditingkatkan dengan memanfaatkan potensi dan peluang yang ada, tentunya harus dibarengi dengan keberlanjutan peningkatan sumberdaya masyarakat dan fasilitasi oleh pihak BBKSDA terutama dalam pembukaan peluang pasar ataupun mitra/jaringan kerja.
\end{abstract}

Kata Kunci : Program Model Desa Konservasi, Konservasi Kawasan Hutan, KPA/KSA Kunyi, Implikasi Program, BBKSDA

\begin{abstract}
The Conservation Village Model Program is a conservation model that provides opportunities for the community to be actively involved and gain safe access in long-term use to support forest area conservation. This utilization access model can vary from one area to another depending on the agreement of the authorities in the management of the area. This study aims to describe the implications of the program on the welfare of the people of Kunyi Village. The community's response was based on 3 indicators, namely knowledge, attitudes, and skills which were tabulated descriptively and then assessed using a Likert scale in the questionnaire assessment, and the measurement of data categories obtained using the Sturges formula. The results of this study conclude that the Conservation Village Model program is considered to have positive implications for the welfare of the community in Kunyi Village and has been able to provide added value to the community's economy. but the value of this income is basically still relatively small when compared to the needs of the community. The value of community income is very likely to be increased by taking advantage of existing potentials and opportunities, of course it must be accompanied by continuous improvement of community resources and facilitation by BBKSDA, especially in opening market opportunities or partners/networks.
\end{abstract}

Keywords: Conservation Village Model Program, Forest Area Conservation, KPA/KSA Kunyi, Program Implications, BBKSDA 


\section{PENDAHULUAN}

Hampir seluruh kawasan konservasi berada dalam pola interaksi yang kuat dengan masyarakat di sekitarnya. Data empiris menunjukkan bahwa jumlah penduduk Indonesia yang tinggal di desa, di dalam, dan sekitar hutan yang kehidupannya bergantung pada sumber daya hutan adalah sekitar 48,8 juta orang, dimana $30 \%$ di antaranya benar-benar bergantung dari hasil hutan (KLHK, 2020). Salah satu penyebabnya adalah terbatasnya akses terhadap kegiatan pembangunan dan pemanfaatan sumber daya alam.

Model konservasi yang memberi peluang kepada masyarakat di kawasan konservasi untuk terlibat aktif dalam upaya pengelolaan kawasan konservasi, dikenal dengan istilah Model Desa Konservasi (MDK). Program MDK telah lama diusung oleh Kementerian Lingkungan Hidup dan Kehutanan cq Direktorat Jenderal Konservasi Sumber Daya Alam dan Ekosistem untuk dikembangkan. Model ini juga memberi peluang kepada masyarakat untuk mendapat akses yang aman dalam pemanfaatan kawasan sehingga dapat menjamin komitmen jangka panjang mereka untuk mendukung konservasi kawasan hutan. Model akses pemanfaatan ini dapat berbeda-beda dari satu kawasan ke kawasan lain tergantung pada kesepakatan dengan pihak yang berwenang dalam pengelolaan kawasan (BBKSDA SulSel, 2015).

Kawasan konservasi BBKSDA Sulawesi Selatan-Sulawesi Barat mencakup dua kawasan konservasi dan kawasan yang terluas adalah Kawasan Taman Nasional Gandang Dewata seluas 189,208.17 hektar dan KPA/KSA Kunyi seluas 988.92 hektar,dimana Desa Kunyi merupakan Model Desa Konservasi yang berbatasan langsung dengan KPA/KSA Kunyi. Model Desa Konservasi merupakan desa yang dijadikan contoh dalam upaya pemberdayaan masyarakat di sekitar kawasan konservasi, sehingga diharapkan MDK dapat menciptakan dan meningkatkan kapasitas masyarakat, mengurangi ketergantungan terhadap kawasan konservasi dan berdampak positif terhadap perlindungan, pengawetan serta pemanfaatan kawasan konservasi (Ichsan dkk., 2017; Effendi dkk., 2014).

MDK di KPA/KSA Kunyi sebagai bagian dari pembangunan kehutanan juga diarahkan untuk mendukung pengelolaan kawasan konservasi, yang disesuaikan dengan fungsi kawasan dimana masyarakat ditempatkan sebagai subjek penting dalam kegiatan tersebut. Keberadaan masyarakat sekitar kawasan merupakan komponen yang secara langsung berinteraksi dengan 
hutan yang berada di sekitarnya (Kusumaningtyas dan Ivan, 2013). Ada beberapa kegiatan yang dilaksanakan pada program MDK di Desa Kunyi Kecamatan Anreapi, yaitu: a) Aktivitas Pengembangan Usaha Alternatif. 1) Pelatihan menjahit 2) Usaha pembibitan tanaman tahunan $b$ ) Peningkatan kualitas sungai 1) Penyuluhan kesehatan lingkungan 2) Pembersihan saluran sungai / kali 3) Pembuatan saluran air limbah c) Biaya produksi pertanian murah 1) Pelatihan pembuatan obat organik 2) Pelatihan pembuatan pupuk organik. Keberhasilan Program MDK akan terwujud apabila ada respon dari masyarakat sekitar yang bisa diketahui dari tingkat kesejahteraan yang mereka rasakan (Mulpiadi dkk., 2015).

Berdasarkan informasi BBKSDA SulSel, desa-desa yang sebelumnya memiliki ketergantungan terhadap kawasan hutan dapat melakukan usaha lain yang bersifat mandiri sehingga secara bertahap kesejahteraan masyarakat dapat meningkat (BBKSDA SulSel, 2015; Iskandar dkk., 2013; Ristianasari dkk.,2013). Desa Kunyi adalah salah satu desa yang mendapatkan program MDK tersebut, karena masyarakat desa ini memanfaatkan lahan hutan untuk pertanian sehingga Desa Kunyi menjadi desa yang mendapat program MDK dari Kementerian Lingkungan Hidup dan
Kehutanan. Terkait hal tersebut diatas, penelitian ini diharapkan dapat menjadi pertimbangan bagi pembangunan Kehutanan melalui MDK yang berimplikasi terhadap kesejahteraan masyarakat Desa Kunyi Kecamatan Anreapi Kabupaten Polewali Mandar Provinsi Sulawesi Barat.

\section{METODE PENELITIAN}

Penelitian ini dilakukan di kawasan konservasi KSA/KPA Kunyi, Desa Kunyi, Kecamatan Anreapi, Kabupaten Polman, Provinsi Sulawesi Barat. Penentuan informan yang dianggap mengetahui objek penelitian, yaitu masyarakat yang menjadi sumber informasi yang dapat memberikan data sesuai dengan masalah yang diteliti. Diketahui jumlah penduduk Desa Kunyi sebanyak 270 KK (BPS, 2020) dan untuk keperluan penelitian diambil sebanyak $10 \%$ s/d $15 \%$ yaitu sekitar 27 s/d 40 KK sebagai informan. Hal ini mengacu kepada pendapat Arikunto (2006), yang menyatakan apabila lebih dari 100 maka sampel atau informan yang diambil sebanyak $10 \%$ s/d $15 \%$ dari jumlah populasi. Undang-Undang No 11 Tahun 2009 juga digunakan sebagai acuan untuk mengetahui implikasi program MDK terhadap kesejahteraan masyarakat setempat, berdasarkan data yang bersumber dari wawancara langsung dengan para 
informan. Respons masyarakat diambil dengan menggunakan quisioner dan ditabulasi, dimana data dibagi kedalam tiga kategori yaitu kategori rendah, sedang dan tinggi. Respons masyarakat didasarkan pada 3 indikator, yaitu pengetahuan, sikap, dan keterampilan. Dalam penilaian quisioner digunakan skala Likert, sedangkan pengukuran kategori data yang diperoleh menggunakan rumus Sturges (dalam Alviana, 2018) dengan rumus : $Z=\frac{X-Y}{K}$

Keterangan :

$\mathrm{Z}=$ Interval kelas

$X=$ Nilai tertinggi

$\mathrm{Y}=$ Nilai terendah

$\mathrm{K}=$ Banyaknya kelas atau kategori

Secara rinci cara pengukuran tingkat pada masing-masing indikator dapat dilihat pada Tabel 1 .

Tabel 1. Cara pengukuran tingkat respon masyarakat Desa Kunyi Terhadap Program Model Desa Konservasi

\begin{tabular}{|c|c|c|c|c|c|c|c|c|}
\hline \multirow[t]{2}{*}{ No. } & \multirow[t]{2}{*}{ Indikator } & \multirow{2}{*}{$\begin{array}{c}\text { Jumlah } \\
\text { pertanyaan }\end{array}$} & \multicolumn{2}{|c|}{$\begin{array}{c}\text { Jawaban } \\
\text { Responden }\end{array}$} & \multirow{2}{*}{$\begin{array}{l}\text { Total Nilai } \\
\quad(30 \\
\text { Responden })\end{array}$} & \multirow{2}{*}{$\begin{array}{l}\text { Selang } \\
\text { kelas }\end{array}$} & \multicolumn{2}{|c|}{$\begin{array}{c}\text { Tingkat respon } \\
\text { Masyarakat }\end{array}$} \\
\hline & & & Kriteria & Nilai & & & Kelas & Skor \\
\hline \multirow{3}{*}{1} & \multirow{3}{*}{ Pengetahuan } & 18 & Rendah & 1 & \multirow{3}{*}{$\begin{array}{c}(30 \times 18 \times 1) \\
\text { s/d } \\
(30 \times 18 \times 3) \\
540 \text { s/d } 1620\end{array}$} & 360 & Rendah & $540-899$ \\
\hline & & & Sedang & 2 & & & Sedang & $900-1259$ \\
\hline & & & Tinggi & 3 & & & Tinggi & $1260-1620$ \\
\hline \multirow{3}{*}{2} & \multirow{3}{*}{ Sikap } & 17 & Rendah & 1 & \multirow{3}{*}{$\begin{array}{c}(30 \times 17 \times 1) \\
\text { s/d } \\
(30 \times 17 \times 3) \\
510 \text { s/d } 1530\end{array}$} & 340 & Rendah & $510-849$ \\
\hline & & & Sedang & 2 & & & Sedang & $850-1189$ \\
\hline & & & Tinggi & 3 & & & Tinggi & $1190-1530$ \\
\hline \multirow{6}{*}{3} & \multirow{3}{*}{ Keterampilan } & 10 & Rendah & 1 & \multirow{3}{*}{$\begin{array}{c}(30 \times 10 \times 1) \\
\text { s/d } \\
(30 \times 10 \times 3) \\
300 \text { s/d } 900\end{array}$} & \multirow[t]{3}{*}{200} & Rendah & $300-499$ \\
\hline & & & Sedang & 2 & & & Sedang & $500-699$ \\
\hline & & & Tinggi & 3 & & & Tinggi & $700-900$ \\
\hline & & \multirow{3}{*}{$\begin{array}{l}18+17+10 \\
\quad=45\end{array}$} & \multirow{3}{*}{\multicolumn{3}{|c|}{$\begin{array}{c}(30 \times 45 \times 1) \text { s/d }(30 \times 45 \times 3) \\
1350 \text { s/d } 4050\end{array}$}} & \multirow{3}{*}{900} & Rendah & 1350 - 2249 \\
\hline & & & & & & & Sedang & 2250 - 3149 \\
\hline & & & & & & & Tinggi & $3150-4050$ \\
\hline
\end{tabular}

\section{Hasil dan Pembahasan}

Berdasarkan hasil wawancara dan jawaban kuisoner yang dilakukan terhadap kegiatan MDK dilihat dari aspek pengetahuan, sikap dan keterampilan, selama proses penelitian diperoleh hasil sebagai berikut : 
Tingkat Respons masyarakat Desa

\section{Kunyi terhadap program MDK}

\section{Pengetahuan.}

Pengetahuan masyarakat diukur berdasarkan dua variabel yaitu 1) Kawasan konservasi dan 2) Model desa konservasi. Variabel Kawasan konservasi berisi 7 pertanyaan kuisoner terkait pengetahuan peraturan, peran upaya konservasi dan fungsi pokok dan pemanfaatan kawasan konservasi. Sedangkan pada variabel model desa konservasi terdapat 11 pertanyaan kuisoner terkait pengetahuan aturan dalam pembentukan MDK, keberadaan lokasi pemukiman dengan KPA-KSA, sosialisasi dan fasilitasi MDK, bentuk pemberdayaan melalui MDK, pembentukan KTH dan perumusan naskah kerjasama dalam program MDK.

Tabel 2. Tingkat pengetahuan masyarakat desa Kunyi terhadap Program Model Desa Konservasi

\begin{tabular}{|c|c|c|c|c|}
\hline \multirow[b]{2}{*}{ No } & \multirow[b]{2}{*}{ Variabel } & \multicolumn{3}{|c|}{ Tingkat Pengetahuan } \\
\hline & & Rendah (\%) & Sedang $(\%)$ & Tinggi (\%) \\
\hline \multirow[t]{8}{*}{1} & Kawasan Konservasi & & & \\
\hline & Peraturan terkait kawasan konservasi & 10 & 85 & 5 \\
\hline & Pentingnya upaya konsevasi & & 90 & 10 \\
\hline & $\begin{array}{l}\text { Kawasan yang masuk/berada disekitar kawasan } \\
\text { memiliki ciri khas tertentu }\end{array}$ & & 63 & 37 \\
\hline & Tumbuhan dan satwa yang dilindungi & 20 & 72 & 8 \\
\hline & $\begin{array}{l}\text { Fungsi pokok KPA-KSA perlindungan sistem } \\
\text { penyangga kehidupan }\end{array}$ & 15 & 85 & \\
\hline & $\begin{array}{l}\text { Fungsi pokok KPA-KSA pengawetan dan } \\
\text { keanekaragaman jenis tumbuhan dan satwa }\end{array}$ & 17 & 83 & \\
\hline & Fungsi pemanfaatan yang terbatas & & 13 & 87 \\
\hline \multirow[t]{12}{*}{2} & Model Desa Konservasi & & & \\
\hline & Peraturan terkait pembentukan MDK & 7 & 83 & 10 \\
\hline & Pengetahuan Program Model Desa Konservasi & & 27 & 73 \\
\hline & $\begin{array}{l}\text { Lokasi pemukiman masuk/berada disekitar } \\
\text { kawasan KPA-KSA }\end{array}$ & & 18 & 82 \\
\hline & $\begin{array}{l}\text { Pengetahuan kawasan sekitar telah ditetapkan } \\
\text { sebagai KPA-KSA }\end{array}$ & & 87 & 13 \\
\hline & Sosialisasi MDK Oleh Balai Besar KSDA & 6 & 13 & 81 \\
\hline & Terbentuknya KTH & 5 & 8 & 87 \\
\hline & $\begin{array}{l}\text { Adanya perumusan bersama terkait naskah } \\
\text { Perjanjian Kerjasama KTH dengan Balai Besar } \\
\text { KSDA }\end{array}$ & 77 & 12 & 11 \\
\hline & $\begin{array}{l}\text { Fasilitasi oleh Balai Besar KSDA dalam } \\
\text { penyusunan proposal }\end{array}$ & & 35 & 65 \\
\hline & $\begin{array}{l}\text { Pemberdayaan masyarakat melalui pelatihan } \\
\text { usaha alternatif menjahit dan pembibitan } \\
\text { tanaman }\end{array}$ & & 35 & 65 \\
\hline & $\begin{array}{l}\text { Pemberdayaan masyarakat melalui kegiatan } \\
\text { sanitasi }\end{array}$ & & 23 & 77 \\
\hline & $\begin{array}{l}\text { Permberdayaan masyarakat melalui pelatihan } \\
\text { pembuatan obat organik dan pembuatan pupuk }\end{array}$ & 5 & 20 & 75 \\
\hline
\end{tabular}


Sesuai dengan hasil pengolahan data diketahui bahwa tingkat respon masyarakat terhadap program MDK berada pada kelas tinggi (3187), hal ini tidak terlepas dari bahwa indikator pengetahuan, sikap dan keterampilan dari responden memang berada pada skor kelas tinggi. Tingkat pengetahuan berada pada skor 1267 (Tinggi), sikap dengan skor 1213 (Tinggi), dan keterampilan memiliki skor 707 (Tinggi)

Berdasarkan hasil penelitian indikator pengetahuan masyarakat desa Kunyi berada pada kelas tinggi, hal ini tidak terlepas dari pengetahuan terkait keberadaan kawasan konservasi pada dasarnya telah ada sejak keluarnya kawasan ini sebelumnya berstatus Hutan Lindung, yang berubah fungsi menjadi kawasan konservasi berdasarkan SK Menteri Kehutanan SK. 726/Menhut-II/2012 tanggal 10 Desember 2012, namun tingkat pengetahuan ini masih lebih cenderung pada pengetahuan yang bersifat belum mendalam (hanya sekedar tahu bahwa beberapa wilayah telah menjadi KPA/KSA Kunyi), hal ini terlihat pada pengetahuan wilayah/lokasi yang masuk dalam kawasan konservasi, fungsi pokok kawasan dan pola pemanfaatan yang dapat dilakukan masih sangat kurang. Namun kehadiran program MDK di desa Kunyi terlihat menjadi jalan dalam pemberian pemahaman yang mendalam bagi masyarakat sekaligus merupakan bentuk usaha pemberdayaan masyarakat yang memiliki ketergantungan cukup besar terhadap kawasan konservasi.

Respon masyarakat desa Kunyi terkait program MDK juga telah mendorong pembentukan Kelompok Tani Hutan (KTH) Benda Lestari. Melalui KTH inilah seluruh program MDK dirumuskan bersama oleh semua anggota dengan melihat potensi dan tingkat ketergantungan ataupun kebutuhan masyarakat dalam upaya-upaya konservasi sekaligus mampu untuk produktif (menghasilkan) yang tentunya tidak melanggar aturan-aturan terkait kawasan konservasi.

Peran serta KTH dalam upaya konservasi inilah dengan sendirinya pula mendorong proses-proses pemberdayaan masyarakat desa Kunyi, melalui serangkaian pendampingan, pemberian pelatihan dan fasilitasi oleh Balai Besar Konservasi Sumber Daya Alam (BBKSDA) Sulawesi Selatan. Dasar acuan dalam proses pemberdayaan ini tentunya diikat pada sebuah perjanjian kerjasama. Berdasarkan hasil penelitian diketahui bahwa kurangnya pelibatan tiap anggota KTH dalam perumusan naskah kerjasama masih begitu tinggi (77\%). Persentase ini tidak terlepas dari pemahaman pengelolaan 
kelembangaan KTH masih begitu kurang. Hal ini tentunya berpengaruh pada penyerapan aspirasi angota yang tentunya berdampak pada tingkat keaktifan anggota terhadap program-program pemberdayaan yang dilakukan oleh kelompok.

\section{Sikap}

Pengukuran sikap masyarakat didasarkan pada dua variabel yaitu 1) Partisipasi perencanaan \& pelaksanaan MDK, dan 2) Partisipasi usaha alternatif, kegiatan sanitasi, dan produksi pertanian murah. Variabel partisipasi perencanaan \& pelaksanaan MDK berisi 8 pertanyaan terkait keikutsertaan responden dalam mendukung (bersikap) terhadap kegiatan dan ketergantungan akan kawasan konservasi, kegiatan sosialisasi MDK, motivasi bergabung dalam KTH, penyusunan proposal MDK, dan keterlibatan dalam perumusan naskah perjanjian kerjasama

Sedangkan pada variabel partisipasi usaha alternatif, kegiatan sanitasi, dan produksi pertanian murah, responden diberikan 7 pertanyaan terkait keikutsertaan dalam pengembangan usaha alternatif menjahit, pembibitan, penyuluhan kesehatan lingkungan, pembersihan saluran air, pembuatan saluran limbah dan pembuatan obat dan pupuk organik. 
Tabel 3. Tingkat sikap masyarakat desa Kunyi terhadap Program Model Desa Konservasi

\begin{tabular}{|c|c|c|c|c|}
\hline & & & Tingkat Sikap & \\
\hline No & Variabel & Rendah (\%) & Sedang (\%) & Tinggi (\%) \\
\hline 1 & $\begin{array}{l}\text { Partisipasi Perencanaan } \\
\text { Pelaksanan MDK }\end{array}$ & & & \\
\hline & \begin{tabular}{lcc} 
Mengikuti & Kegiatan & \multicolumn{2}{c}{ Sosialisasi } \\
perencanaan pelaksanaan & MDK yang \\
diadakan pihak BKSDA &
\end{tabular} & & 15 & 85 \\
\hline & $\begin{array}{l}\text { Ikut serta dalam menyusun proposal } \\
\text { kegiatan MDK }\end{array}$ & 75 & 20 & 5 \\
\hline & $\begin{array}{l}\text { Ikut menjadi peserta dalam pelatihan } \\
\text { peningkatan kapasitas yang diadakan } \\
\text { pihak BKSDA }\end{array}$ & & 10 & 90 \\
\hline & Ikut bergabung dalam KTH & & & 100 \\
\hline & $\begin{array}{l}\text { Keikutsertaan dalam kelompok } \mathrm{KTH} \\
\text { karena diajak }\end{array}$ & 10 & 18 & 72 \\
\hline & $\begin{array}{l}\text { Keikutsertaan dalam kelompok KTH } \\
\text { karena keinginan sendiri }\end{array}$ & 86 & 7 & 7 \\
\hline & Hadir dalam pertemuan rutin KTH & & & \\
\hline & $\begin{array}{l}\text { Keterlibatan dalam perumusan naskah } \\
\text { perjanjian kerjasama antara KTH dengan } \\
\text { BKSDA terkait program MDK }\end{array}$ & 70 & 23 & 7 \\
\hline & $\begin{array}{l}\text { Ikut mendukung pengelolaan kawasan } \\
\text { konservasi }\end{array}$ & 6 & & 94 \\
\hline & Ketergantungan terhadap kawasan & & 27 & 73 \\
\hline 2 & $\begin{array}{l}\text { Partisipasi Usaha alternatif, Kegiatan } \\
\text { Sanitasi, dan Produksi Pertanian } \\
\text { Murah }\end{array}$ & & & \\
\hline & $\begin{array}{l}\text { Ikut serta pada kegiatan pengembangan } \\
\text { usaha alternatif menjahit }\end{array}$ & & 54 & 46 \\
\hline & $\begin{array}{l}\text { Ikut serta pada kegiatan usaha alternatif } \\
\text { pembibitan }\end{array}$ & & 11 & 89 \\
\hline & $\begin{array}{l}\text { Ikut serta pada kegiatan sanitasi berupa } \\
\text { Penyuluhan Kesehatan Lingkungan }\end{array}$ & & 15 & 85 \\
\hline & $\begin{array}{l}\text { Ikut serta pada kegiatan sanitasi berupa } \\
\text { Pembersihan Saluran Air }\end{array}$ & & 14 & 86 \\
\hline & $\begin{array}{l}\text { Ikut serta pada kegiatan sanitasi berupa } \\
\text { Pembuatan Saluran Limbah }\end{array}$ & & 20 & 80 \\
\hline & $\begin{array}{l}\text { Ikut serta pada kegiatan pelatihan } \\
\text { pembuatan obat organik }\end{array}$ & & 15 & 85 \\
\hline & $\begin{array}{l}\text { Ikut serta pada kegiatan pelatihan } \\
\text { pembuatan pupuk organik }\end{array}$ & & 13 & 87 \\
\hline
\end{tabular}

Hasil penelitian menunjukkan bahwa respon sikap masyarakat Desa Kunyi terkait program MDK menunjukkan berada pada skor 1213 yang berarti berada pada kelas tinggi. Sikap masyarakat terhadap perencanaan dan pelaksanaan MDK 
meskipun secara umum berada pada tingkat tinggi, namun diketahui ada beberapa variabel penelitian yang berada dalam tingkat sikap yang rendah yaitu pada variabel keikutsertaan dalam penyusunan proposal kegiatan MDK (75\%), hal ini menunjukkan masih tingginya sikap masyarakat untuk tidak ikut serta dalam penyusunan proposal MDK. Tingkat sikap yang rendah juga terlihat pada variabel keikutsertaan masyarakat dalam kelompok KTH atas keinginan sendiri (86\%) dan 70\% terkait kecilnya keterlibatan tiap anggota KTH dalam perumusan naskah perjanjian kerjasama antara KTH dengan BKSDA pada program MDK.

Sikap masyarakat dalam berpartisipasi sangat ditentukan oleh tingkat pemahaman dan gambaran awal apa yang akan diperoleh dalam program MDK. Kurangnya keikutsertaan dalam penyusunan proposal kegiatan MDK, kecilnya keikutsertaan masyarakat dalam kelompok KTH atas keinginan sendiri dan kurangnya keterlibatan tiap anggota $\mathrm{KTH}$ dalam perumusan naskah perjanjian kerjasama didorong oleh pemahaman terhadap MDK secara personal maupun institusional yang masih begitu minim.

Dibutuhkan upaya kolektif dari para pemangku kepentingan dalam hal ini KTH dan BBKSDA untuk tetap kontinyu melakukan pemberian pemahaman sehingga partipasi masyarakat dalam perencanaan dan pelaksanaan kegiatan MDK dapat optimal. Pelibatan masyarakat menjadi penting mengingat masyarakat sudah tinggal di sekitar atau di dalam kawasan konservasi sebelum kawasan tersebut ditetapkan (Eko, 2013). Di sisi lain, besarnya partisipasi masyarakat dalam usaha alternatif, kegiatan sanitasi, dan produksi pertanian murah lebih cenderung didorong oleh adanya kejelasan apa yang akan diperoleh oleh masyarakat dari kegiatan tersebut, selain harapan akan adanya pengetahuan dan keterampilan baru, juga sangat ditunjang oleh pemahaman umum bahwa seluruh kegiatan tersebut biasanya akan mendapatkan penganggaran (biaya operasional, honorarium, dan sebagainya)

\section{Keterampilan}

Variabel dalam melihat tingkat keterampilan masyarakat terhadap MDK diukur melalui 10 pertanyaan terkait kemampuan dan keterampilan responden setelah difasilitasi melalui kegiatan pemberdayaan dalam program MDK. 


\section{Tabel 4. Tingkat keterampilan masyarakat desa Kunyi terhadap Program Model Desa} Konservasi

\begin{tabular}{|c|c|c|c|c|}
\hline \multirow[b]{2}{*}{ No } & \multirow[b]{2}{*}{ Variabel } & \multicolumn{3}{|c|}{ Tingkat Keterampilan } \\
\hline & & Rendah (\%) & Sedang $(\%)$ & Tinggi (\%) \\
\hline \multirow[t]{11}{*}{1} & Program Model Desa Konservasi & & & \\
\hline & $\begin{array}{l}\text { Keterampilan usaha secara mandiri } \\
\text { sehingga tidak bergantung pada kawasan } \\
\text { konservasi }\end{array}$ & & 87 & 13 \\
\hline & $\begin{array}{l}\text { Keterampilan usaha secara berkelompok } \\
\text { sehingga tidak bergantung pada kawasan } \\
\text { konservasi }\end{array}$ & & 70 & 30 \\
\hline & Kemampuan menjahit & 20 & 50 & 30 \\
\hline & $\begin{array}{l}\text { Kemampuan pemasaran hasil usaha } \\
\text { menjahit }\end{array}$ & 58 & 27 & 15 \\
\hline & $\begin{array}{l}\text { Dapat melakukan pembibitan tanaman } \\
\text { tahunan }\end{array}$ & & 5 & 95 \\
\hline & $\begin{array}{l}\text { Mampu mengelola lingkungan yang } \\
\text { sehat }\end{array}$ & & 42 & 58 \\
\hline & $\begin{array}{l}\text { Mampu mengelola saluran air dengan } \\
\text { baik }\end{array}$ & & 37 & 63 \\
\hline & Mampu mengelola saluran limbah & & 68 & 32 \\
\hline & Dapat membuat obat organik & & 52 & 48 \\
\hline & Dapat membuat pupuk organik & & 49 & 51 \\
\hline
\end{tabular}

Untuk mendapatkan tingkat respons masyarakat terhadap program MDK berdasarkan kelas rentang yang telah ada, skor ketiga indikator masing-masing pengetahuan, sikap, dan keterampilan ditambahkan seperti disajikan pada Tabel 5.

Tabel 5. Tingkat respon masyarakat desa Kunyi terhadap Program Model Desa Konservasi

\begin{tabular}{cccc}
\hline \multirow{2}{*}{ No } & Indikator & \multicolumn{2}{c}{ Tingkat Respon Masyarakat Terhadap Program MDK } \\
\cline { 3 - 4 } & & Skore & Kelas Rentang \\
\hline 1 & Pengetahuan & 1267 & Tinggi \\
\hline 2 & Sikap & 1213 & Tinggi \\
\hline 3 & Keterampilan & 707 & Tinggi \\
\hline
\end{tabular}


Hasil penelitian menunjukkan bahwa keterampilan berada pada skor 707, yang berarti masuk dalam kategori kelas tinggi. Pada umumnya masyarakat setelah mengikuti program MDK telah memiliki keterampilan dasar yang berada pada persentase tingkat keterampilan sedang dan tinggi. Namun ada beberapa variabel penelitian dimana keterampilan masyarakat berada pada tingkat keterampilan rendah yaitu pada variabel keterampilan pemasaran hasil usaha menjahit (58\%). Rendahnya variabel keterampilan ini ditunjang oleh belum adanya fasilitasi terkait bantuan alat (mesin jahit) dan metode pemasaran dilain sisi juga bahwa pada umumnya kegiatan menjahit didasarkan pada ada tidaknya pemesanan. Fasilitasi terkait metode pemasaran menjadi penting kedepannya sehingga masyarakat yang telah mendapatkan fasilitasi keterampilan menjahit benar-benar dapat memperoleh manfaat terkhusus pada peningkatan ekonomi keluarga, sehingga dengan sendirinya ketergantungan ekonomi terhadap kawasan konservasi dapat berkurang.

\section{Implikasi program MDK terhadap}

\section{kesejahteraan masyarakat Desa Kunyi}

Tindakan untuk menjaga dan melestarikan kawasan tentunya tidak selalu muncul dari inisiatif masyarakat sendiri, tetapi perlu didorong dan diarahkan oleh pihak lain. Selain itu masyarakat perlu merasakan adanya keuntungan bagi mereka sehingga akan lahir kemandirian dalam mengembangkan perilaku di bidang ekonomi, hal ini dimaksudkan agar masyarakat mempunyai pengetahuan, persepsi dan sikap serta kemampuan dalam meningkatkan ekonomi tanpa merusak kawasan.

Hasil penelitian dan wawancara mendalam diketahui bahwa rata-rata penghasilan 30 responden Rp. 500.000. Hal ini menunjukkan bahwa program MDK pada KPA/KSA Kunyi telah mampu memberi nilai tambah ekonomi masyarakat. namun nilai pendapatan ini pada dasarnya masih relatif kecil bila dibandingkan dengan kebutuhan masyarakat. Nilai pendapatan masyarakat sangat berpeluang untuk ditingkatkan dengan memanfaatkan potensi dan peluang yang ada, tentunya harus dibarengi dengan keberlanjutan peningkatan sumberdaya masyarakat dan fasilitasi oleh pihak BBKSDA terutama dalam pembukaan peluang pasar ataupun mitra/jaringan kerja.

Meskipun secara umum responden mempunyai sikap dan persepsi baik terhadap cara-cara dalam meningkatkan pendapatan tanpa merusak kawasan melalui program MDK, namun sangat penting 
untuk tetap merumuskan upaya-upaya keberlanjutan atas sikap dan persepsi yang disesuaikan dengan karakteristik masyarakat agar tetap sejalan dengan tindakan konservasi dalam tujuan lahirnya kemandirian ekonomi. Sebagaimana penelitian Ristianasari, dkk (2013) bahwa upaya meningkatkan pemahaman terhadap karakteristik masyarakat dan menerapkan pendekatan pemberdayaan yang sesuai dengan kondisi masyarakat merupakan hal penting dan relevan dalam mewujudkan kemandirian sebagai dampak pemberdayaan MDK.

\section{KESIMPULAN}

Respons masyarakat Desa Kunyi terhadap program MDK berada pada kategori kelas Tinggi, yang berarti program Model Desa Konservasi (MDK) berimplikasi positif terhadap kesejahteraan masyarakat di Desa Kunyi telah mampu memberi nilai tambah ekonomi masyarakat. namun nilai pendapatan ini pada dasarnya masih relatif kecil bila dibandingkan dengan kebutuhan masyarakat. Nilai pendapatan masyarakat sangat berpeluang untuk ditingkatkan dengan memanfaatkan potensi dan peluang yang ada, tentunya harus dibarengi dengan keberlanjutan peningkatan sumberdaya masyarakat dan fasilitasi oleh pihak BBKSDA terutama dalam pembukaan peluang pasar ataupun mitra/jaringan kerja.

\section{DAFTAR PUSTAKA}

Arikunto, S. 2006. Prosedur Penelitian, Suatu Pendekatan Praktek. PT. Rineka Cipta. Jakarta

BBKSDA SulSel, 2015. KSA/KPA Kunyi Kabupaten Polewali Mandar Provinsi Sulawesi Barat. http://www.ksdasulsel.org/fronten $\mathrm{d} /$ web/kawasan-konservasi ?id=1520314103

BPS, 2020. Kabupaten Polman Dalam Angka. Badan Pusat Statistik Provinsi Sulawesi Barat.

Effendi AD, Roland A. Barkey, Muh. Hatta Jamil. 2014. Strategi Pengembangan Program Pemberdayaan Masyarakat Pada Model Desa Konservasi Di Taman Nasional Taka Bonerate. Jurnal Sains \& Teknologi Vol.14 No.2 : $151-161$

Eko Wahyu Budi Yanto. 2013. Partisipasi Masyarakat dalam Usaha Konservasi Hutan. Journal of Educational Social Studies Vol. 2 No.1 : 29-33

Ichsan AC, Rinekso Soekmadi, Soeryo Adiwibowo, Cecep Kusmana. 2017. Peran Pemangku Kepentingan Dalam Pelaksanaan Model Desa Konservasi Di Taman Nasional Gunung Rinjani. Jurnal Analisis Kebijakan Kehutanan Vol. 14 No.1 : 47- 59

Iskandar, Hasan Almutahar, M. Sabran. 2013. Kajian Sosiologis Terhadap Peran Penyuluh Kehutanan Dalam Pemberdayaan Masyarakat Pada Pengelolaan Hasil Hutan Bukan Kayu (HHBK) Di Desa Tunggul Boyok Kecamatan Bonti 
Kabupaten Sanggau. Jurnal Tesis PMIS-UNTAN-PSS-2013 : 1-26

KLHK, 2020. Sumber Pangan Masyarakat Sekitar Hutan. Biro Hubungan Masyarakat Kementerian Lingkungan Hidup dan Kehutanan, Jakarta. http://ppid.menlhk.go.id/berita/sia ran-pers $/ 5898$

Kusumaningtyas, R. dan Ivan Chofyan. 2013. Pengelolaan Hutan dalam Mengatasi Alih Fungsi Lahan Hutan Di Kabupaten Subang. Jurnal Perencanaan Wilayah dan Kota, Vol.13 No.2 : 1-11

Mulpiadi, Soetoro, Tito Hardiyanto. 2015. Respon Petani Terhadap Kegiatan
Model Desa Konservasi (MDK) di Kawasan Taman Buru Masigit Kareumbi (Studi Kasus Pada Kelompok MDK di Desa Sindulang Kecamatan Cimanggung Kabupaten Sumedang). Agroinfo Galuh Vol 2 No $1: 35-40$

Ristianasari, Pudji Muljono, Darwis S. Gani. 2013. Dampak Program Pemberdayaan Model Desa Konservasi Terhadap Kemandirian Masyarakat : Kasus Di Taman Nasional Bukit Barisan Selatan Lampung. Jurnal Penelitian Sosial dan Ekonomi Kehutanan Vol. 10 No. 3 : 173 185 